\title{
Lip and Oral Cavity Cancer Pathologic Primary Tumor TNM Finding v7
}

National Cancer Institute

\section{Source}

National Cancer Institute. Lip and Oral Cavity Cancer Pathologic Primary Tumor TNM

Finding v7. NCI Thesaurus. Code C88940.

A pathologic finding about one or more characteristics of lip and oral cavity cancer,

following the rules of the TNM AJCC V7 classification system as they pertain to staging of the primary tumor. 